\title{
Strengthening Financial System Regulation: The Nigerian Case
}

\author{
*Godwin E. Uddin", \\ Anthony O. Monehin 1 \\ Emeka Osuji ${ }^{2}$

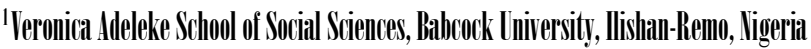

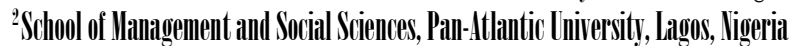

\begin{abstract}
Many studies have considered the efficacy of the Central Bank of Nigeria (CBN)'s monetary policy to ensure Deposit Money Banks (DMBs) performance in Nigeria but scantily mentioned in literature are assertions on other roles that the Asset Management Corporation of Nigeria (AMCON) - an agency aligned to the CBN, could perform to further strengthen the efficacy of the CBN's monetary policy (and/or macro/microprudential guidelines) in financial sector management, even so during this CovID-19 pandemic and afterward, and besides AMCON's statutory role of debt recovery. Also, the need for initiatives that could inform efforts to strengthen the efficacy of CBN's policy instruments, despite post-2010 debt-recovery activities by AMCON, remains. Thus, this review article examines the activities of AMCON and their implications on $\mathrm{CBN}^{\prime} s$ policy instruments design/formulation and implementation in Nigeria. Our findings thereof include AMCON contributes to DMBs' surveillance which could inform CBN's policy instruments design/formulation, and that the basis of the association between CBN and AMCON is prominent in respect to policy instruments' implementation and compliance. Therefore, this study recommends CBN to leverage on AMCON's recurrent interface with DMBs to further strengthen the operational effectiveness of so established policy instruments.

Keywords: Monetary policy, Deposit Money Banks (DMBS), Central Bank of Nigeria (CBN), Asset Management Corporation of Nigeria (AMCON), Coronavirus (COVID-19)
\end{abstract}

JEL: E5, E52, E58, G28

Asset Management Companies (AMCs) are reputed to be trusted agencies in a bid for the management of systemic crisis that emerges in world economies, with examples in Asia - recall the Asian Financial Crisis ${ }^{1}$, Europe - in countries such as Ireland, Spain, and Africa - which as of 2009 , the second-largest (and now largest) economy Nigeria was hit hard by the global financial crisis that originated from the United States of America. But then, irrespective of their capabilities i.e., AMCs to address potential stress factors in Deposit Money Banks (DMBs) which outplay as precursors to such events, Central Banks - saddled purposefully with the mandate to ensure financial sector sanity through monetary policy design (and/or macro/microprudential guidelines formulation) and implementation - in respective countries and increasingly common these days to work with certain financial system supervisory units/arms/agencies aligned to them (inclusive of AMCs) continually demand of DMBs to practice prudent management of loan books and compliance to ethical corporate 
governance conduct among other expectations as a form of proactive stance to prevent such outburst misdemeanor (Ani, 2013; Boissay and Cappiello, 2014; Botha and Makina, 2011; Butaru et al., 2016; Cerruti and Neyens, 2016; de Haan and Kakes, 2020; Faia and Schnabel, 2015; Hansen, 2012; Hussaini, 2018; Mankiw, 2010; Osinski, Seal and Hoogduin, 2013; Tatliyer, 2017).

Also, efforts, therefore, to avoid a lacuna in the operational effectiveness of established monetary policy decisions (and/or macro/microprudential guidelines) to evade (the occurrence of) potential or full-blown financial crisis (Caruana, 2014; Committee on Global Financial System [CGFS], 2010; Committee on Global Financial System [CGFS], 2012; Farhi and Tirole, 2012; Hanson, Kashyap and Stein, 2011; International Monetary Fund [IMF], 2013; Kashyap, Berner and Goodhart, 2011; Keys et al., 2010; Schularick and Taylor, 2012; Shin, 2010a; 2010b) invariably or more often than not lead for cross-correspondence between financial institutions (DMBs, etc.) and the Central Bank as well as to other financial system supervisory units/arms/agencies aligned to the Central Bank, one of which in Nigeria is the Asset Management Corporation of Nigeria (AMCON) (Botha and Makina, 2011; Caruana, 2014; Ezema, 2015; Godwin, 2017; Jimoh, 1994; Osinski et al., 2013).

It is in line with the foregoing that in Nigeria, the Central Bank of Nigeria (CBN) seeks to ensure compliance to macroprudential and microprudential guidelines (or regulations) by DMBs, and at the same time functions with an operationally-associated agency (such as AMCON) for debt recovery due to defaulting loan obligations, in view to guarantee soundness in the country's financial system (Caruana, 2014; Ezema, 2015).

More so, the history of development of the banking sector in Nigeria is evident that most of the failures (low capital adequacy, low profit before/after tax (PBT or PAT), low earning per share (EPS), low return on equity $(\mathrm{ROE})$, low return on asset (ROA), unfavorable debt-equity ratio, unfavorable loan-deposit ratio, among others) experienced within the sector (and which partly led to the eventual merger/buy-off or acquisition/non-existence of some of the (bank) financial institutions) were results of improper lending, rising bad loans/non-performing loans (NPLs), inside-bank "sharppractices"/insider-abuses/unethical corporate governance conducts, asset-maturity and liquidity mismatch etc. (see Figure 1) (Akinsola and Odhiambo, 2017; Akpan, 2013; Ayodele, 2014; Ezema, 2015; Fofack, 2005; Ikpesu, Akinola and Ikpesu, 2020; Olajide, Asaolu and Jegede, 2011; Onaolapo, 2012; Onoh and Nwachukwu, 2017; Tarus, 2015), and the prevalence of these aforementioned not checked continually could undermine the statutory function of AMCON (i.e., her debt recovery role) on behalf of the CBN, the overall functions of the CBN for financial sector (or system) sanity, and onward profitability of DMBs in the country, Nigeria (Abiola, 2014; Kolapo, Ayeni and Oke, 2012; Ogboi and Unuafe, 2013).

Nevertheless, the recent efforts by the monetary authority in Nigeria - the CBN - to foster lending 


\section{Uddin et al.}

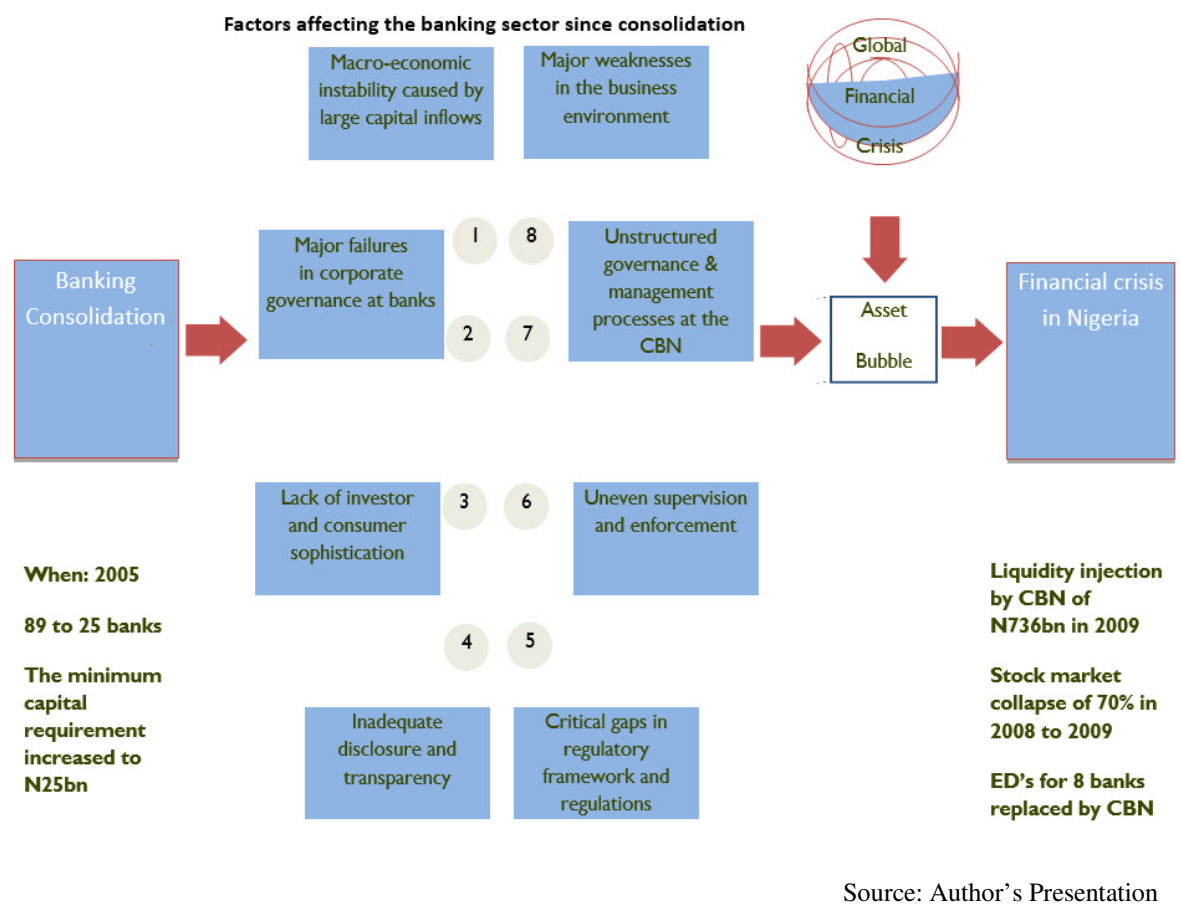

Figure 1. Banking Sector in Nigeria, 2005 and Afterward

to "real sector"" activities (CBN, 2019a; 2019b; 2019c; 2019d; 2020a), and now these times to enable recovery of the Nigerian economy from the "hinges" of the novel coronavirus (or COVID-19) pandemic (CBN, 2020b; 2020c; 2020d; Evans, 2020) also duly call for the need for DMBs to comply to prudent credit proposal analyses, prudent loan request evaluation, and prudent business financing implementation, as evoked by AMCON, to avoid a repeat of (similar) findings from a financial sectorwide stress test for DMBs as implemented in 2009 in the country, Nigeria and evade a systemic panic/bank runs.

The CBN thence is statutorily recognized for monetary policy design (and/or macro/microprudential guidelines formulation) (Ezema, 2015; Ojo, 2013; Shitile, 2013; Uchendu, 2009) and somewhat assisted in these policy instruments' implementation by certain operationally-associated financial system supervisory units/arms/agencies (one of which is AMCON) (Abata, 2015; Akpan, 2013), but evident in history is the possible "weak" efficacy of so established policy instruments (Caruana, 2014; Olajide, Asaolu and Jegede, 2011). Hence, still the need thereof for initiatives that could further inform strengthening the efficacy of the CBN's policy instruments, for preserving DMBs' health (and or financial system soundness).

To this end, the purpose of this study is to examine the activities of AMCON and her activities' impl- 
ications on CBN's policy instruments design/formulation and implementation in Nigeria, in view to contribute expert opinion that could further inform efforts to strengthen the operational effectiveness of so established policy instruments, even during these times of the COVID-19 pandemic and afterward, and thus a question underlying this research is: what role does the Asset Management Corporation of Nigeria (AMCON) have to play in monetary policy design (and/or macro/microprudential guidelines formulation) and implementation in Nigeria?

Be that as it may, some studies (such as Akomolafe et al., 2015; Ayodele, 2014; Ekong and Udonwa, 2015; Ogbeifun and Akinola, 2019; Okheshimi, 2020; Okorie and Agu, 2015; Olajide, Asaolu and Jegede, 2011; Onoh and Nwachukwu, 2017, etc.) notably had made a case on the efficacy of the CBN's monetary policy to ensure DMBs' performance (and/or financial sector sanity), but scantily attested on other roles that AMCON - a supervisory agency aligned to the CBN - could perform to further strengthen the efficacy of CBN's monetary policy (and/or macro/microprudential guidelines) in financial sector management, in contemporary time beyond 2018 (see Okheshimi, 2020 - which is the latest known in the series of related empirical research), and during this COVID-19 pandemic and afterward, besides AMCON's statutory role of debt recovery.

A few review articles such as Botha and Makina (2011), Caruana (2014), Godwin (2017) bring into context a consideration of the roles that financial system supervisory units/arms/agencies aligned to a Central Bank could perform to help further strengthen the efficacy of the Central Bank's monetary policy (and/or macro/microprudential guidelines) as a similar discourse such as one herein, but none specifically addressed the case of Nigeria and a possible way forward during these times of the novel coronavirus (COVID-19) pandemic and afterward.

To quickly put, this review article adopts the twin peaks model of financial regulation (Botha and Makina, 2011; Godwin, 2017), and thereby attests as of the Nigerian environment some other roles that AMCON could perform to further strengthen the efficacy of the CBN's monetary policy design (and/or macro/microprudential guidelines formulation) and implementation in Nigeria, an improvement to the considerations made by previous studies (Abata, 2015; Akpan, 2013; Akomolafe et al., 2015; Ayodele, 2014; Ekong and Udonwa, 2015; Ogbeifun and Akinola, 2019; Okheshimi, 2020; Okorie and Agu, 2015; Olajide, Asaolu and Jegede, 2011; Onoh and Nwachukwu, 2017, etc.).

The rest of this article continues as follows; Section 2 entails the stylized facts. Section 3 reiterates the literature review. Section 4 provides the methodology, while Section 5 presents the discussions and section 6 concludes the discourse.

\section{Stylized Facts}

\section{-Overview and History of AMCON}




\section{Uddin et al.}

Established by the Act of the National Assembly of Nigeria in 2010, the Asset Management Corporation of Nigeria (AMCON) was purposeful to be a buyer of banks for the Nigerian Government by acquiring the non-performing loans (NPLs) and such deemed necessary following the wake and aftermath of the 2007/2008 global financial crisis and some domestic events (see Figure 1, Table 1 and 2-Appendix-I, II). At inception, among 10 banks identified to have asset-quality issues (or serious asset-quality risk), the situation faced by three ${ }^{3}$ of these banks necessitated an urgent injection of N736 billion liquidity to buy up their assets which thereby led to AMCON's take over (Alford, 2011; Cerruti and Neyens, 2016; Egwuatu, 2012; Eigner and Umlauft, 2015; Makanjuola, 2015; Tatliyer, 2017; Temin, 2010). Thus, in a way, AMCON could be regarded as a product (or consequence) of circumstance to ensure the affected banks remained a going concern (Ogun, 2012).

Additionally, a feature that preceded AMCON was the monetary authority - the CBN's resolve to implement the Nigerian Banking Sector Reform in 2009, and of which such undertaking included the carrying out of stress test on Nigerian DMBs. Amidst the findings notable, besides some corporate governance issues etc., was the notice of NPLs among the DMBs in a manner so chronic that selected DMBs were in prudence declared as insolvent. In context, these NPLs accounted for credits or borrowed funds extended by these DMBs, and these (i.e., the NPLs) for at least 90 days did not generate income and or were not re-paid (Abata, 2015; Alford, 2011; Cerruti and Neyens, 2016; Egwuatu, 2011).

Still, some other obvious concerns prevalent in the banking sector such as non-compliance to minimum capital requirements, over-exposure to volatile segments like the oil and gas sector and capital market, at that time in Nigeria made a case for an agency as AMCON to be instituted and to act in place to purchase toxic assets from banks and consequently after the purchase ensure the assisted banks maintain a healthy balance sheet (Abata, 2015; Cerruti and Neyens, 2016; Egwuatu, 2012).

\section{-Functions of AMCON}

The assigned tasks to AMCON, from inception, notably include the promotion of efforts to ensure a strong legal framework, adherence to ethical corporate governance structure, as well as operational autonomy among players especially banks in the Nigerian financial system. Thence, with a timely intervention to support the restructuring of the banking sub-sector in Nigeria given the growth in NPLs, cases of insolvency, and illiquidity among banks, the mandate assumed by this allied-monetary agency/institution are as follows: (i) acquisition (ii) management, and (iii) disposition of assets in accordance to the act upon which her existence was effective (Aldor, 2013; Ani, 2013).

The AMCON duly plays a role in assisting, especially DMBs in Nigeria, to recapitalize, make invest- 
International Journal of Management, Economics and Social Sciences

ment and or acquire/purchase assets from financial houses, raise optimal returns on assets in their custody (inclusive of collection of interest on the principal, principal, and capital gain), manage inflows and mitigate risk on such assets, and dispose of these assets as at when due in compliance to the provisions of the AMCON Act 2010 (Cerruti and Neyens, 2016; Hussaini, 2018). Yet, the aspect of whether to or not to handle the securitization of loans is still undecided (Ani, 2013).

Though in recent times, there are arguments which recount the need for the AMCON to be defunct or non-existent, and in a way for the CBN/Federal Government of Nigeria to discontinue the "babysitting" or the assurance of possible bailout of financial institutions (i.e., DMBs etc.) whenever in distress because of the tendency of presently sound financial institutions comprising the Nigerian financial system towards privilege-abuse by same financial institutions (Agabi and Onayemi, 2016; Kuye, Ogundele and Obaro, 2013; Olutokun, James and Olorunfemi, 2013).

\section{-Central Bank of Nigeria-Monetary Policy}

Monetary policy is acclaimed to influence the level of the money stock and/or interest rate, the value and cost of credit in consonance with the level of economic activity, as well as able to play the role to ensure overall macroeconomic stability. By definition, monetary policy could be referred to as the combination of measures designed to regulate the value, supply, and cost of money in the economy to achieve macroeconomic balance (Akomolafe et al., 2015; CBN, 2011; Oke, 1995; Uchendu, 2009). In Nigeria, the use of monetary policy as an instrument of monetary control dates back to the Central Bank Act of 1958 upon which the CBN was established with the responsibility of formulating and implementing monetary policy, and over the years these monetary policy instruments had been either direct or indirect. Until 1993, the CBN relied almost exclusively on varying combinations of direct instruments of monetary control such as credit ceilings, sectoral credit allocation, interest rate controls, the imposition of special deposits, moral suasion, stabilization securities, and exchange rate control (Ojo, 2013; Uchendu, 2009).

With the advent of some macroeconomic reforms in the mid-1980s, the CBN started the process of shifting from the use of direct instruments to market-based instruments. The most significant move in the new direction came in June 1993 when the CBN introduced a market-based instrument known as open market operations (OMO), which involves the supply or withdrawal of liquidity from the economy by the CBN through secondary market dealings in treasury securities and issuance/purchase of Central Bank securities (Uchendu, 2009).

In other words, OMO entails the sale or purchase of eligible bills or securities in the open market by the CBN to influence deposit money banks' reserves balances, the level of base money, and consequently the overall level of monetary and financial conditions. The transactions carried out in 


\section{Uddin et al.}

OMO are outright sales or purchases of securities in the market, repurchase transactions (REPOS), and matched sales purchase transactions (Ojo, 2000).

Other market-based instruments introduced in addition to OMO were: reserve requirement which specifies the proportion of DMB's total deposit liabilities that should be kept with the CBN, and discount window operations under which the CBN performs the role of lender of last resort to DMBs, as well as moral suasion adopted as a means of establishing two-way communication with DMBs thereby creating a better environment for the effectiveness of monetary policy (Nnanna, 2001). Nevertheless, despite the appreciable progress made since the introduction of various financial sector reforms in the 1980s, monetary policy management in Nigeria is still faced with severe challenges as the expected stabilization and growth benefits may sometimes fail to materialize (Onyeiwu, 2012).

\section{-Macro/Microprudential Guidelines in Nigeria}

There are three cadres, however, of policy instruments in decreasing levels of coverage as used by Central Banks to manage the financial system: (i) Monetary policy instruments, (ii) Macroprudential policy instruments, and (iii) Microprudential policy instruments. Whereas, monetary policy instruments or tools could be categorized into standard measures (inclusive of key rates, open market operations, standing facilities, and reserve requirements) and non-standard measures, with respective objectives, while prudential policy instruments are preventive measures meant to abort potential problems (Beyer et al., 2017).

Macroprudential policy instruments refer to varied measures for preserving the soundness of the financial system. They are to contribute to the stability of the financial system, thereby safeguarding the financial system against the build-up of systemic risk. Their implementation helps to contain systemic risks by enforcing actions that help keep overall sectoral (or systemic) activities, of all DMBs collectively, for example, at certain levels or thresholds. In an analogical perspective, macroprudential policy instruments focus on the forest (financial system), not the trees (individual financial institutions) with the objective of controlling the likelihood of financial system distress and limiting its costs to the economy (Beyer et al., 2017; Shitile, 2013).

In Nigeria, macroprudential policy instruments include (1) Disclosure Regulations - this is enforced so as to ensure the provision of information that could help proper consideration of impending systemic risks. The Financial Policy and Regulation Department (FPRD) of the CBN is saddled with this responsibility of preparation and dissemination of Financial Stability Report; (2) Credit growth caps this is to mitigate and prevent excessive credit growth and leverage in system-wide (lending) activities; (3) Countercyclical capital buffer - this is to enhance financial system stability by reducing the impact of financial cycles, with financial institutions having adequate capital to withstand. Such assistance 
though is never extended without charges. Nonetheless, its effectiveness will depend on inflationary pressure and the business cycle in the domestic economy; and (4) Accounting Rules - this had been implemented since 2012, to expose the Nigerian banking system to the global best practices in financial reporting and disclosure, with the adoption of the International Financial Reporting Standard (IFRS) in the country's banking system (Shitile, 2013).

By way of implementation, the macroprudential policy instruments remain a work in progress. Some concerns thereof in the use of these measures include the gap in maintaining a system of control between rules and discretionary judgments, and the issue of strengthening the capacity to check for excessive behavior that may lead to having a full-blown crisis (Shitile, 2013).

On the other hand, microprudential policy instruments relate to varied measures for ensuring the soundness of individual financial institutions (mostly DMBs). They contribute to the safety and soundness of individual entities, and thereby contribute to the stability of the financial system as a whole. Their implementation helps ensure compliance with regulatory standards on bank capital adequacy, leverage ratios, and liquidity. In addition, these measures for individual institution-level financial regulation aid to guarantee solvency, or robust balance sheets of financial institutions to shocks, and ensure consumer protection (Beyer et al., 2017; Ezema, 2015).

For the Nigerian financial system, microprudential policy instruments include: (1) Restrictions on asset holdings and activities - this is to discourage DMBs from taking excessive risks by constraining the category of assets that DMBs could hold, and by directly preventing DMBs from going into risky and non-core business engagements. (2) Limits on competitive activities - these restrictions are set to discourage DMBs from engaging in excessive risk-taking solely for-profit motive and to guide competition in the industry. Examples here include restrictions on entry and exit, restrictions on foreign participation, restrictions on branching. (3) Statutory capital requirements - this is aimed to ensure adequate capital, which acts as buffers in hard times. The capital requirements take different forms (including leverage ratios, capital ratios, risk-adjusted ratios etc.) and they are to compel DMBs to hold additional capital buffers that are easily available in times of financial difficulties, to enable DMBs to absorb losses, without hindering their operations. The idea is to increase the amount of capital held by DMBs so that in the event of any unanticipated shock, the DMBs could absorb the shock and be able to remain in business without requiring bailout. (4) On-site/off-site bank examination - the conduct of bank examination by regulators is for them to verify the claim of DMBs in complying with the extant regulation(s), and to determine whether to take enforcement actions where there is no or low compliance. For example, in a case of diverse ownership, an indication is required of the DMB of the shareholding structure, and then restrictions could be on the number (or percentage) of shares 


\section{Uddin et al.}

held by certain categories of shareholders, so as to prevent such categories of people obtaining absolute control of DMBs (Ezema, 2015).

Lastly, the implementation of microprudential policy instruments also is not devoid of some challenges. One to mention is the inability of microprudential policy instruments to address the crosssectional dimension of systemic risks that arises directly from inter-bank lending activities (Ezema, 2015).

\section{LITERATURE REVIEW}

\section{Theoretical Underpinnings}

\section{-The Twin Peaks Model of Financial Regulation}

The basic economic rationale for financial regulation had been that financial market activity could generate externalities that are not easily addressed by private agents, and the problem is that externalities generate social cost in the event of failure, especially when this cost is greater than the private cost and the social cost does not form part of the decision-making function of the institutions, especially DMBs (Botha and Makina, 2011). More so, Falkena et al. (2001) assert that when financial systems are left to themselves, they have been found to be prone to spells of instability and contagion. Hence, prudential supervision of DMBs stems from the basis that DMBs through their role in maturity transformation and the provision of liquidity has a special position in the financial system, and the goal of supervision is to prevent potentially excessive risk-taking by requiring DMBs to hold larger reserves than they might otherwise do and to conduct their business with more careful attention to risk, amidst others (Davies and Green, 2008).

However, in practice, consensus prevail for shift from the silos (institutional) or integrated (unified) model of financial regulation - which had been the traditional approach that appropriate financial regulation solely to the Central Bank, and in which the Central Bank takes responsibility for all prudential and systematic regulation of the banking sector, monitoring information disclosure and providing solvency support, as well as being the sole custodian for the regulation of the conduct of day-to-day business in the sector - to the twin peaks (horizontal) model of financial regulation which is premised on assigning some regulatory activities to some entities external but aligned to the Central Bank, and in which there is a form of regulation by objective, one in which there is somewhat a shared supervisory function with one institution (the Central Bank) performing the overall safety and soundness supervision, and all other supervisory entities complementing the Central Bank's other adhoc oversight (or supervision), such as the regulation of the conduct of day-to-day business (inclusive of consumer protection) (Godwin, 2017; Taylor, 1995). 
Though an advantage posited of the silos (institutional) or integrated (unified) model of financial regulation, over the twin peaks (horizontal) model of financial regulation, is its unified focus on regulation and supervision without confusion or conflict over jurisdictional lines, but some shortcomings noted include that it could create "the risk of a single point of regulatory failure", and that in the process of regulating the activities of DMBs, the vertical regulatory role or the single universal regulator status of the Central Bank could provide space for regulatory arbitrage whereby tighter regulation in one or some financial services undertakings is compensated by these same DMBs moving operations to another or some other financial services undertakings where regulation is not too tight (Botha and Makina, 2011).

The twin peaks (horizontal) model of financial regulation is so designed to incorporate the efficiencies and benefits of the silos (institutional) or integrated (unified) model, and also to make provision for conflict that may exist between consumer protection and transparency, safety, and soundness regulation objectives. Australia, the Netherlands, Belgium, New Zealand are some of the countries that make use of the twin peak approach, and its merits have been considered by countries such as France, Italy, Spain, and the United States (G30, 2008).

\section{Empirical Review}

Tables 3 (see Appendix-III) and 4 (see Appendix-IV) summarize the published literature (or peerreviewed/scientific documents) on the efficacy of (Central Bank) monetary policy vis-à-vis DMBs performance, as well as on financial system supervisory institutions and (Central Bank) monetary policy in tabular form.

In summary, from the literature, it is evident that the relationship between monetary policy variable - money supply - and DMBs performance has been mixed, in the same vein as the relationship between other monetary policy variables and DMBs performance. But, none of these studies had considered the period beyond 2018 i.e., the years shortly before the COVID-19 pandemic (or the part of the late period in the pre-COVID-19 era (see Okheshimi, 2020), and even more especially these times of the COVID-19 pandemic.

Nevertheless, in as much as the efficacy of monetary policy had been examined, only a few review articles had considered the role that financial system supervisory units/arms/agencies aligned to a Central Bank could perform to help further strengthen the efficacy of the Central Bank's monetary policy, and none considered specifically the Nigerian context, alongside specific reference to other roles by AMCON. This exploratory study, therefore, adopts the twin peaks model of financial regulation (Botha and Makina, 2011; Godwin, 2017), and thereby attests as of the Nigerian environment some other roles that AMCON could perform to further strengthen the efficacy of the CBN's monetary policy 


\section{Uddin et al.}

design (and/or macro/microprudential guidelines formulation) and implementation in Nigeria, a contribution as an improvement to the considerations made by previous studies (Abata, 2015; Akpan, 2013; Akomolafe et al., 2015; Ayodele, 2014; Ekong and Udonwa, 2015; Ogbeifun and Akinola, 2019; Okheshimi, 2020; Okorie and Agu, 2015; Olajide, Asaolu and Jegede, 2011; Onoh and Nwachukwu, 2017 etc.).

The issues presented in Tables 3 and 4 also notably are expressed related, because monetary policy remains not an end in itself, but rather a means to an end, i.e., the instance of certain financial system supervisory units/arms/agencies working with the Central Bank could, in the first place, help strengthen financial system (or banking sector) regulation, and resultantly preserve DMBs' health (or foster DMBs performance/financial system soundness) (Caruana, 2014). While, by extension, to include the empirical consideration of the efficacy of monetary policy (and/or macro/microprudential guidelines) for DMBs performance in the discourse herein, would be beyond the focus of this study ${ }^{4}$.

\section{METHODOLOGY}

This article, in a succinct manner, considered existing published literature (or peer-reviewed/scientific documents) to examine the activities of AMCON, and her activities' implications on CBN's policy instruments design/formulation and implementation in Nigeria. The tripartite methodological process for this review article proceeds as follows:

Search for relevant literature: This process, the first stage, involved the search for (and/or exploration) of relevant literature delimited, out of convenience, to 70 articles amidst others, and sourced from reputed databases (or depositories) hosted by the following institutions (Table 5, Appendix-V). This search strategy for the 70 relevant articles/reports amidst others was undertaken using keywords such as monetary policy, macro/microprudential guidelines, financial crisis, Asset Management Companies, and Asset Management Corporation of Nigeria.

Observing the parts: This second stage entailed partly, an alignment to renowned articles, and overall to consult literature on the subject matter - monetary policy, macro/microprudential guidelines, financial crisis, Asset Management Companies, Asset Management Corporation of Nigeria, etc. Also, this review article was developed along salient themes drawn, and as thoughts, perspectives, and or implications established from the consulted literature. The themes upon which the 70 relevant literature amidst others sourced from the aforementioned databases (or depositories) were (chosen and) analyzed include monetary policy in Nigeria, macro/microprudential guidelines in Nigeria, macro.microprudential guidelines and global financial crisis, macro/microprudential guidelines and debt recovery, the CBN-AMCON nexus, and macro/microprudential guidelines and COVID-19 pandemic. 
Use of the literature: The third stage was a snowball (or snowballing) presentation of the survey of the (relevant) literature made, and the consideration and or discussion of the literature were not simply recitation/repetition of same but echoes of findings of the present review commensurate to answer the research question.

Lastly, it is noteworthy that evidence of conceptual narrative(s)/meta-narrative(s) procedure - a type of review of literature - as a research method ${ }^{5}$ for review articles, and as utilized for this research could be appreciated in works such as Baumeister and Leary (1997), Burton (2014), Snyder (2019), Wong et al. (2013), etc.

\section{DISCUSSION}

\section{AMCON and CBN Policy Instruments Design/Implementation in the Nigerian Economy}

The existence of AMCs is noted in the literature to be of global practice as well as not of a novel concept, and that they serve as a vehicle to restructure insolvent banks in respective economies alongside to mop up illiquid loans or assets in DMBs comprising partly a country's financial system. More so, they (i.e., AMCs) are recounted to act in place to rescue failing DMBs (and or minimize the high cost of public bailouts) and help ensure the government derives value from the rescued DMBs. Thus, AMCs are recognized purposeful with the main function to facilitate the process of financial system restructuring and enable the recovery of non-performing assets at the same time, a concern which in Nigeria is overseen by the monetary authority - the CBN but the later in a delegated manner handled or carried out by AMCON (Agabi and Onayemi, 2016; AMCON, 2019; Cerruti and Neyens, 2016; Igbokwe, 2017).

Whereas, AMCs in the discharge of four often identified roles of (a) selling, (b) recovering, (c) restructuring, and (d) writing-off of non-performing assets in distressed DMBs, makes them reputed in managing the potential (or full-blown) crisis that emerge in world economies' financial system. Meanwhile, their intervention, in distressed DMBs, to separate bad assets from good ones is recounted to allow for a proper evaluation of the health of a DMB, and such separation deemed advantageous to free up liquidity and enable DMBs to engage in new lending (Agabi and Onayemi, 2016; Cerruti and Neyens, 2016; Igbokwe, 2017).

Notably, the Central Bank's mandate to draw up (certain) monetary policy instruments, as well as macro/micro-prudential guidelines to mitigate and or ensure the non-prevalence of systemic panic/bank runs amidst other reasons or objectives ensue as a task that requires or solicits information on the health of especially DMBs (Caruana, 2014), and in Nigeria, the foregoing endeavor is vividly brought to bear as "fruit" or as a result of recurrent monitoring of DMBs' activities by the CBN, and of 


\section{Uddin et al.}

which AMCON in their recurrent interface with same DMBs could also contribute to affect such surveillance focused to inform monetary policy design (and/or macro/microprudential guidelines formulation) (Figure 2, Dashes = non-statutory roles, a/b=Indirect/Direct complementary enforcement) (CBN, 2011; Hussaini, 2018).

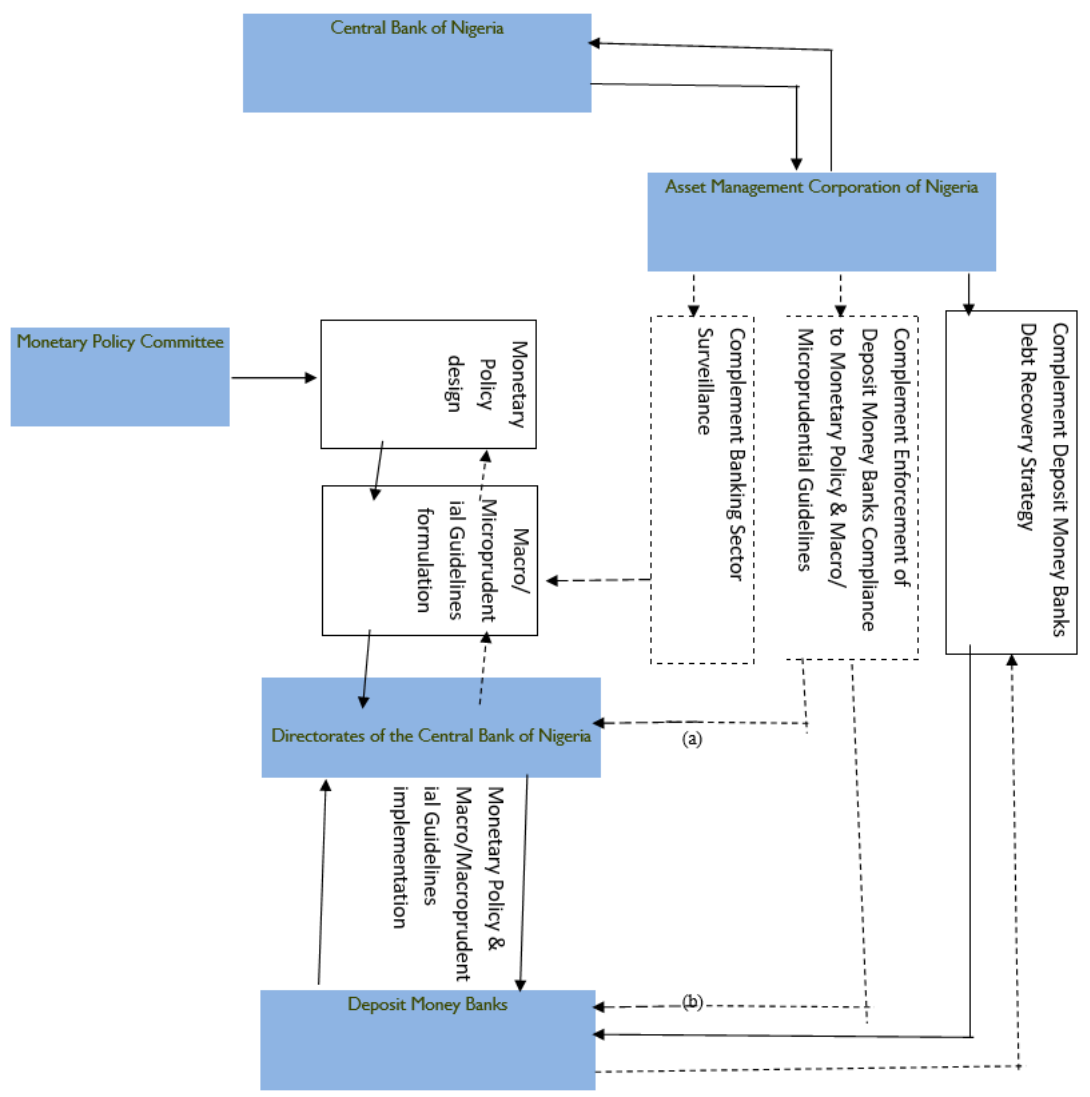

Source: Authors' Presentation

Figure 2. The CBN-AMCON Nexus

However, monetary policy (and/or macro/microprudential guidelines) implementation (accompanied with efforts to ensure compliance) stands out prominently as the basis of the supposed association between the CBN and AMCON in Nigeria. In view to ensure financial system sanity, as such stance (or modus operandi) envisage correspondence from DMBs to the CBN as well as to other financial system supervisory units/arms/agencies aligned to the CBN (inclusive of AMCON) (Figure 2) (Caruana, 2014; Cerruti and Neyens, 2016; Ezema, 2015; Hussaini, 2018; Shitile, 2013).

In sum, the AMCON could duly complement the CBN in her procedure to ensure compliance of DMBs to monetary policy injunctions as well as macro/microprudential guidelines stipulated from time 
to time, as they both at same time follow-up same DMBs in respect of day-to-day liquidity management, capital adequacy requirements, and undertakings relating to avoidance of assetmaturity/cash withdrawal mismatch amidst others (see Figure 2) (Akpan, 2013; Aldor, 2013; Ani, 2013; Cerruti and Neyens, 2016; Hussaini, 2018; Mmadu, 2010). In other words, the AMCON could support the CBN in ensuring the stability of the Nigerian financial system (Igbokwe, 2017).

\section{COVID-19 Pandemic, CBN Policy Instruments, and AMCON in Nigeria}

Still on the discourse presented here, the recent spate of cases being recorded of the infamous coronavirus, commonly referred to as COVID-19 and documented to have originated in Wuhan, China with its outbreak in December 2019, has notably thrown the world into a state of panic and while scientists all over the world continually strive to understand the complexity of this aforementioned virus, the ravaging menace of this COVID-19 pandemic has left governments, institutions and people everywhere scampering for any and every solution (CBN, 2020e; Evans, 2020).

Consequently, efforts (and/or measures) promoted by the World Health Organization (WHO, 2020) as well as federal and municipal/state governments of world economies to mitigate the spread of the COVID-19 infection had included the wearing of face masks, ban of large gatherings/promotion of social distancing, closure of educational institutions, business (or firms') closures, implementation of nationwide/total or regional/local lockdown, etc. (WHO, 2020; NCDC, 2020). Whereas, now after some time of putting into effect the foregoing measures, and in view to enable phased return or gradual easing of the practice of day-to-day business, the possibility of people to go about their varied means of livelihood, and reopening of the world economies for business activities, experience has shown there is remarkably the need for world governments (institutions) to incentivize businesses (or firms) with funds as bail-out aid or "soft money" to enable their continued operation, prevent further job losses, and foster eventual economy-wide recovery from a potential recession that could be caused by the crippling of business activities due to the COVID-19 pandemic (Business Day Newspaper, 2020; CBN, 2020e).

Meanwhile, a recent official report from the Chinese National Bureau of Statistics shows China often scandalized to be the originator of the coronavirus pandemic - to record 3.2 percent Q2 2020 Gross Domestic Product (GDP) growth, and this is of similar aspiration to other world economies, including Nigeria as the feat is termed attributable to various business support measures consisting increased fiscal spending, tax relief, etc. amid the government efforts to ease the nation's lockdown (CNBC, 2020).

In the case of Nigeria thereof, to encourage business re-openings (despite the periodic closure in compliance to state lockdown, and risk of non-survival/non-continuity/non-profitability in the interim), 


\section{Uddin et al.}

to enable economy-wide recovery from the "pangs" of the COVID-19 pandemic, the Nigerian monetary authority - the CBN - had duly launched and sought to implement different business relief packages as some of her monetary policy responses to meet the financing needs of businesses in face of the COVID-19 pandemic realities (CBN, 2020b; 2020c; 2020d). Although since mid-2019, the CBN had remarkably maintained a pronounced stance directing all DMBs in the country to more aggressively support real sector lending activities (CBN, 2019a; 2019b; 2019c; 2019d; 2020a).

But then to recoup these extended facilities to businesses by DMBs on behalf of the CBN (and/or in line with the CBN's monetary policy responses), even in these times of the COVID-19 pandemic (CBN, 2020b; 2020c; 2020d) and post COVID-19 going forward, entertains the services of AMCON in their follow-up correspondence with DMBs due to the need to ensure repayment of the extended loan facilities by businesses assisted, to ensure the continued profitability of DMBs, to avoid a repeat of similar findings of the 2009 financial sector-wide DMBs' stress test in Nigeria, and evade a systemic panic/bank runs (see Figure 2). Likewise, such concern as of the function of AMCON here raised will also aid DMBs in their recoup of already extended loan facilities pre-COVID-19 (i.e., recovery of overdue loan obligations from defaulting borrowers), following a fruitful implementation of the recently released Global Standing Instruction (GSI) by the CBN (see Figure 2) (CBN, 2020f).

\section{CONCLUSION}

In conclusion, this discourse shows the relationship between CBN and AMCON concerning monetary policy design (and or macro- and microprudential guidelines formulation) and implementation. It was established from our exploration of relevant literature, and the research question herein answered with the notion that the recurrent interface of AMCON with DMBs on behalf of the CBN helps provide a wealth of information which could go a long way to inform CBN's policy instruments design/formulation as related in Hussaini (2018); whereas also, the coordinated handling of correspondence from DMBs to the CBN, and invariably to AMCON could enable/foster the efficacious implementation of CBN's policy instruments (and or enforcement of compliance of DMBs to these policy instruments) in view to ensure financial system sanity as highlighted in Caruana (2014) and Cerruti and Neyens (2016).

\section{RECOMMENDATION}

Thus, it is recommended that the CBN should leverage on AMCON's recurrent interface with DMBs, in efforts to further strengthen the operational effectiveness of so established policy instruments, even in this period of the COVID-19 pandemic and post COVID-19. 


\section{FUTURE DIRECTIONS}

Finally, consequent to our exploratory review of literature, we assert the need for further financial sector-related studies (empirical or otherwise) examining the efficacy of CBN's monetary policy (and/or macro/microprudential guidelines) for DMBs performance in contemporary time beyond 2018 (see Okhesimi, 2020). In this time of the COVID-19 pandemic, and at post-COVID-19, in view to proffering more opinion that could further inform efforts to strengthen the operational effectiveness of so established policy instruments. Similarly, the same contextual considerations as above may be extended to other African, Asian, and South American economies.

\section{REFERENCES}

Abata, M. A. (2015). Impact of Asset Management Corporation of Nigeria (AMCON) on the securitization in the Nigerian banking sector. Global Journal of Contemporary Research in Accounting, Auditing and Business Ethics, 1(2): 282-298.

Abiola, I. (2014). The impact of credit risk management on commercial banks' performance in Nigeria. International Journal of Management and Sustainability, 3(5): 295-306.

Agabi, I. \& Onayemi, A. (2016). Troubled assets resolution. In O. Olanipekun (Ed.), Banking theory, regulation, law, and practice: 284-312. Lagos, Nigeria: Au Courant

Akinsola, F. A. \& Odhiambo, N. M. (2017). The impact of financial liberalization on economic growth in sub-Saharan Africa. Cogent Economics and Finance, 5(1): 1-11.

Akomolafe, K. J., Danladi, J. D, Babalola, O. \& Abah, A. G. (2015). Monetary policy and commercial banks' performance in Nigeria. Public Policy and Administration Research, 5(9): 158-166.

Akpan, A. U. (2013). The relevance of the Asset Management Corporation of Nigeria (AMCON) to the non-performing loans of deposit money banks. International Journal of Economics, Business, and Finance, 1(8): 249-261.

Aldor, D. E. (2013). Reforms of the Nigerian banking system, assessment of the Asset Management Corporation of Nigeria (AMCON), and recent development. Social Research Journal, 20(16): 1-21.

Alford, D. (2011). Nigerian banking reforms: recent actions and prospects. Retrieved October 15, 2019, from http://www. proshareng.com/articles/2268

AMCON (2019). Achievements. Retrieved October 15, 2019, from https://amcon.com.ng/achievements.php

Ani, W. U. (2013). Managing the financial sector crisis in Nigeria through AMCON. The African Business Review, 5, 37-40.

Ayodele, J. C (2014). Effects of monetary policy on commercial bank lending in Nigeria. Review of Public Administration and Management, 3(5): 134-146.

Baumeister, R. F. \& Leary, M. R. (1997). Writing narrative literature reviews. Review of General Psychology, 1, 311-320.

Beyer, A., Nicoletti, G., Papadopoulou, N., Papsdorf, P., Runstler, G., Schwarz, C., Sousa, J. \& Vergote, O. (2017). The transmission channels of monetary, macro-, and microprudential policies and their interrelations. Occasional Paper Series 191/May 2017, Frankfurt, Germany: European Central Bank (ECB)

Boissay, F. \& Cappiello, L. (2014). Micro- versus macro-prudential supervision: Potential differences, tensions, and complementarities. ECB Financial Stability Review, 135-140.

Botha, E. \& Makina, D. (2011). Financial regulation and supervision: Theory and practice in South Africa. The International Business and Economics Research Journal, 10(11): 27-36.

Burton, L. D. (2014). Doing research (part 1): Finding a problem to investigate. Journal of Research on Christian Education, 23(1): $1-4$.

Business Day Newspaper (2020) Lagos streamlines guidelines on easing of COVID-19 lockdown. Retrieved July 7, 2020, from https://businessday.ng/coronavirus/article/lagos-streamlines-guidelines-on-easing-of-covid-19-lockdown/

Butaru, F., Chen, Q., Clark, B., Das, N., Lo, A. W. \& Siddique, A. (2016). Risk and risk management in the credit card industry. Journal of Banking and Finance,72, 218-239.

Caruana, J. (2014). The role of central banks in macroeconomic and financial stability. In M. S. Mohanty (Ed.), The role of central banks in macroeconomic and financial stability: 1-5. Bank for International Settlements (BIS) Paper 76, Monetary and Economic Department.

Central Bank of Nigeria - CBN (2011). What is monetary policy? Understanding Monetary Policy Series, No 1. Abuja, Nigeria: Central Bank of Nigeria.

Central Bank of Nigeria - CBN (2019a). Letter to all banks: Regulatory measures to improve lending to the real sector of the Nigerian economy. July 3, 2019. Abuja, Nigeria: Central Bank of Nigeria.

Central Bank of Nigeria - CBN (2019b). Communique no 125 of the monetary policy committee meeting of Monday $22^{\text {nd }}$ and Tuesday 23 $3^{\text {rd }}$ July 2019. Abuja, Nigeria: Central Bank of Nigeria. 


\section{Uddin et al.}

Central Bank of Nigeria - CBN (2019c). Letter to all banks: New offer letter clause for credit facilities. August 26, 2019. Abuja, Nigeria: Central Bank of Nigeria.

Central Bank of Nigeria - CBN (2019d). Letter to all banks: Re: Regulatory measures to improve lending to the real sector of the Nigerian economy. September 30, 2019. Abuja, Nigeria: Central Bank of Nigeria.

Central Bank of Nigeria - CBN (2020a). Letter to all banks: Re: Regulatory measures to improve lending to the real sector of the Nigerian economy. January 7, 2020. Abuja, Nigeria: Central Bank of Nigeria.

Central Bank of Nigeria - CBN (2020b). Circular to deposit money banks and the general public on CBN policy measures in response to COVID-19 outbreak and spillovers. March 16, 2020. Abuja, Nigeria: Central Bank of Nigeria.

Central Bank of Nigeria - CBN (2020c). Circular to deposit money banks and the general public: Guidelines for the implementation of the N50 billion targeted credit facility. March 23, 2020. Abuja, Nigeria: Central Bank of Nigeria.

Central Bank of Nigeria - CBN (2020d). Communique no 129 of the monetary policy committee meeting of Monday $23^{\text {rd }}$ and Tuesday $24^{\text {th }}$ March 2020. Abuja, Nigeria: Central Bank of Nigeria.

Central Bank of Nigeria - CBN (2020e). Communique no 130 of the monetary policy committee meeting of Thursday $28^{\text {th }}$ May 2020. Abuja, Nigeria: Central Bank of Nigeria.

Central Bank of Nigeria - CBN (2020f). Circular to all banks and other financial institutions: Operational guidelines on global standing instruction (GSI) - Individuals. July 13, 2020. Abuja, Nigeria: Central Bank of Nigeria.

Cerruti, C. \& Neyens, R. (2016). Public asset management companies: A toolkit. Washington D. C., United States of America: International Bank for Reconstruction and Development - IBRD / World Bank.

CNBC (2020) China says its economy grew $3.2 \%$ in the second quarter this year, rebounding from coronavirus. Retrieved July 7 , 2020, from https://www.cnbc.com/2020/07/16/china-economy-beijing-reports-q2-2020-gdp.html

Committee on Global Financial System (CGFS) (2010). Macro-prudential instruments and frameworks: A stocktaking of issues and experiences. CGFS Papers, No 38, Bank for International Settlements (BIS).

Committee on Global Financial System (CGFS) (2012). Operationalizing the selection and application of macroprudential instruments, CGFS Papers, No 48, Bank for International Settlements (BIS).

Davies, H. \& Green, D. (2008). Global financial regulation: The essential guide. Bodmin, Cornwall: MPG Books Ltd.

de Haan, L. \& Kakes, J. (2020). European banks after the global financial crisis: Peak accumulated losses, twin crises, and business models. Journal of Banking Regulation, 21, 197-211

Egwuatu, P. (2011). AMCON has addressed problems of non-performing loans. Retrieved October 15, 2019, from https://www.vanguardngr.com/2011/07/amcon-has-addressed-problems-of-non-performing-loans-cbn/

Egwuatu, P. (2012). CBN, AMCON, SEC set to boost investors' confidence. Retrieved October 15, 2019, from https://www.vanguardngr.com/2012/04/cbn-amcon-sec-set-to-boost-investors-confidence/

Eigner, P. \& Umlauft, T. S. (2015). The great depression(s) of 1929 - 1933 and 2007 - 2009? Parallels, differences and policy lessons, MTA-ELTE Crisis History Working Paper No. 2.

Ekong, U. M. \& Udonwa, U. E. (2015). Banking sector reforms and the performance of commercial banks in Nigeria. Journal of World Economic Research, 4(3): 45- 60. Retrieved October 15, 2019, from http://article.sciencepublishinggroup.com/html/10.11648.j.jwer.20150403.11.html

Evans, O. (2020). Socio-economic impacts of novel coronavirus: The policy solutions. BizEcons Quarterly, 7, 3-12.

Ezema, C. C. (2015). Micro-prudential regulation, Understanding Monetary Policy Series No 59, Abuja, Nigeria: Central Bank of Nigeria.

Faia, E. \& Schnabel, I. (2015). The road from micro-prudential to macro-prudential regulation. In E. Faia, A. Hackethal, M. Haliassos \& K. Langenbucher (Eds.), Financial regulation: A transatlantic perspective: 3-23. Cambridge, United Kingdom: Cambridge University Press.

Falkena, H., Bamber, R., Llewellyn, D \& Store, T. (2001). Financial regulation in South Africa (Second Edition). South Africa Financial Sector Forum.

Farhi, E. \& Tirole, J. (2012). Collective moral hazard, maturity mismatch, and systemic bailouts. American Economic Review, 102(1): 60-93.

Fofack, H. (2005). Non-performing loans in sub-Saharan Africa: Causal analysis and macroeconomic implications. World Bank Policy Research Working Paper No. 3769.

G30 (2008). The structure of financial supervision: Approaches and challenges in a global marketplace. Group of Thirty - G30, Washington D. C., USA.

Godwin, A. (2017). Introduction to the special issue - the twin peaks model of financial regulation and reform in South Africa. Law and Financial Markets Review, 11(4):151-153.

Hansen, L. P. (2012). Challenges in identifying and measuring systemic risk. National Bureau for Economic Research (NBER) Working Papers, No 18505.

Hanson, S. Kashyap, A. \& Stein, J. (2011). A macro-prudential approach to financial regulation. Journal of Economic Perspectives, 25(1): 3-28.

Hussaini, H. (2018). AMCON and asset management. Retrieved October 15, 2019, from https://www. pressreader.com/nigeria/thisday/20180305/281526521558842

Igbokwe, M. I. (2017). Receivership under the AMCON act: Scope and application. Retrieved October 15, 2019, from https://www.insol.org/_files/Africa

Ikpesu, F., Akinola, A. \& Ikpesu, O. A. (2020). Remittance flows and banking sector development in emerging markets: Do institutions matter? Journal of Transnational Management. Retrieved August 08, 2020, from https://doi.org/10.1080/15475778.2020.1788916 
International Monetary Fund (IMF) (2013). Key aspects of macro-prudential policy. Washington, D. C.: International Monetary Fund (IMF).

Jimoh, A. (1994). Regulation of the banking industry in Nigeria: An operator's viewpoint. Central Bank of Nigeria (CBN) Economic and Financial Review, 32(3): 292-311.

Kashyap, A., Berner, R. \& Goodhart, C. (2011). The macro-prudential toolkit. International Monetary Fund (IMF) Economic Review, 59, 145-161.

Keys, B., Mukharjee, T., Seru, A. \& Vig, V. (2010). Did securitization lead to lax screening? Evidence from subprime loans. Quarterly Journal of Economics, 125(1): 307-362.

Kolapo, T. F., Ayeni, R. K. \& Oke, M. O. (2012). Credit risk and commercial banks' performance in Nigeria: A panel model approach. Australian Journal of Business and Management Research, 2(2): 31-38.

Kuye, O. L., Ogundele, O. J. \& Obaro, A. O. (2013). The government bailout of financially distressed banks in Nigeria: A justifiable strategy? International Journal of Business and Social Sciences, 4(8): 174-180.

Makanjuola, Y. (2015). Banking reform in Nigeria: The aftermath of the 2009 financial crisis. In Palgrave Macmillan Studies in Banking and Financial Institutions. London, United Kingdom: Palgrave Macmillan.

Mankiw, N. G. (2010). Macroeconomics (7th ed.). New York, USA: Worth Publishers.

Mmadu, R. A. (2010). Workability and effectiveness of the Asset Management Corporation of Nigeria. International Journal of Advanced Legal Studies and Governance, 3, 41-56.

Nigeria Centre for Disease Control - NCDC (2020) Press release: 100 days of Nigeria's COVID-19 response. Retrieved July 7 , 2020, from https://covid19.ncdc.gov.ng/guideline/

Nnanna, O. J. (2001). Monetary policy framework in Africa: The Nigerian experience. Abuja, Nigeria: Central Bank of Nigeria. Retrieved October 21, 2019, from https://nairametrics.com/wp-content/uploads/2011/10/Monetary-Policy-Framework-inAfrica.pdf

Oduyemi, A. O. (2013). The real sector. Understanding Monetary Policy Series 33. Abuja: Central Bank of Nigeria.

Ogbeifun, I. E. \& Akinola, A. O. (2019). Impact of qualitative monetary policy on the performance of deposit money banks in Nigeria. International Journal of Development Research, 9(7): 28833-28840.

Ogboi, C. \& Unuafe, O. K. (2013). Impact of credit risk management and capital adequacy on the financial performance of commercial banks in Nigeria. Journal of Emerging Issues in Economics, Finance and Banking, 2(3): 703-717.

Ogun, O. (2012). An appraisal of the Asset Management Corporation of Nigeria (AMCON) act 2010. Retrieved October 15, 2019, from https://topeadebayollp.wordpress.com/2012/02/28/an-appraisal-of-the-asset-management-corporation-ofnigeria-amcon-act-2010/

Ojo, M. O. (2000). Principles and practice of monetary management in Nigeria. Abuja, Nigeria: Central Bank of Nigeria.

Ojo, M. O. (2013). Transition to full-fledged inflation targeting: A proposed program for implementation by the Central Bank of Nigeria. Occasional Paper No. 44. Abuja, Nigeria: Central Bank of Nigeria.

Oke, B. A. (1995). The conduct of monetary policy by the Central Bank of Nigeria, 1959 - 1995. Central Bank of Nigeria Economic and Financial Review, 33(4): 289-294.

Okheshimi, E. N. (2020). Monetary policy and commercial banks' assets quality in Nigeria: Panel Data Analysis. American International Journal of Economics and Finance Research, 2(1): 54-71.

Okorie, M. C. \& Agu, D. O. (2015). Does banking sector reform buy the efficiency of banking sector operations? Evidence from recent Nigeria's banking sector reforms. Asian Economic and Financial Review, 5(2): 264-278.

Olajide, O. T., Asaolu, T. \& Jegede, C. A. (2011). The impact of financial sector reforms on banks' performance in Nigeria. The International Journal of Business and Finance Research, 5(1): 53-63.

Olutokun, G. A., James, O. O \& Olorunfemi, K. (2013). Bank distress in Nigeria and the Nigerian Deposit Insurance Corporation intervention. Global Journal of Management and Business Finance Research, 13(8): 1-16.

Onaolapo, A. R. (2012). Analysis of credit risk management efficiency in Nigeria commercial banking sector (2004 - 2009). Far East Journal of Marketing and Management, 2(4): 39-52.

Onoh, J.O \& Nwachukwu, T. (2017). Monetary policy and credit delivery in commercial banks - Evidence from Nigeria. International Journal of Social Sciences and Management Research, 3(7): 19-47.

Onyeiwu, C. (2012). Monetary policy and economic growth of Nigeria. Journal of Economics and Sustainable Development, $3(7): 62-70$.

Osinski, J., Seal, K. \& Hoogduin, L. (2013). Macro-prudential and micro-prudential policies: Towards cohabitation. IMF Staff Discussion Note (SDN).

Schularick, M. \& Taylor, A. (2012). Credit booms gone bust: Monetary policy, leverage cycles, and financial crisis, 1870 2008. American Economic Review, 102(2): 1029-1061.

Shin, H. (2010a). Risk and liquidity (Clarendon Lectures in Finance ed.). Oxford, United Kingdom: Oxford University Press.

Shin, H. (2010b). Macro-prudential policies beyond Basel III. Policy Memo, Princeton University.

Shitile, T. S. (2013). Macro-prudential regulation, Understanding Monetary Policy Series No 25, Abuja, Nigeria: Central Bank of Nigeria.

Snyder, H. (2019). Literature review as a research methodology: An overview and guidelines. Journal of Business Research, 104, $333-339$.

Tarus, D. K. (2015). Do diaspora remittances affect banking sector development in sub-Saharan Africa? International Journal of Commerce and Management, 25(3): 356-368.

Tatliyer, M. (2017). The 2008 - 2009 financial crisis in historical context. In U. Hacioglu \& H. Dincer (Eds.), Global financial crisis and its ramifications on capital markets: $3-17$. Cham, Switzerland: Springer 


\section{Uddin et al.}

Taylor, M. (1995). Twin Peaks: A Regulatory Structure for the New Century. London, UK: Centre for the Study of Financial Innovation.

Temin, P. (2010). The great recession and the great depression. Daedalus, 139(4): 115- 124. Retrieved October 15, 2019, from https://doi.org/10.1162/DAED_a_00048

The Sun (2015). AMCON hands over Enterprise, Mainstreet banks to new owners. Retrieved October 15, 2019, from /http://sunnewsonline.com/new/amcon-hands-over-enterprise-mainstreet-banks-to-new-owners/

Uchendu, O. A. (2009). Overview of monetary policy in Nigeria. Central Bank of Nigeria Bulletin, 30(2): 10-20.

Uddin, G. \& Oserei, K. (2019). Positioning Nigeria's manufacturing and agricultural sectors for global competitiveness. Growth and Change, 50(3): 1218-1237.

Wong, G., Greenhalgh, T., Westhorp, G., Buckingham, J. \& Pawson, R. (2013). RAMSES publication standards: Meta-narrative reviews. BMC Medicine, 11, 20. https://doi.org/10.1186/1741-7015-11-20

World Health Organization - WHO (2020). Coronavirus disease (COVID-19) advice for the public. Retrieved July 7, 2020, from https://www.who.int/emergencies/diseases/novel-coronavirus-2019/advice-for-public

\section{ACKNOWLEDGEMENT}

The authors appreciate the mentorship of Ch. Mahmood Anwar, Associate Editor, International Journal of Management, Economics and Social Sciences (IJMESS), Peter Frederik Lanjouw, Professor of Economics at Vrije Universiteit, Amsterdam, Netherlands and Editor-in-Chief, World Bank Research Observer, Samson Alika, Central Bank of Nigeria, Abuja, Nigeria, Adegbemi Onakoya, Associate Professor, Department of Economics, Veronica Adeleke School of Sciences, Babcock University, Ilishan-Remo, Ogun State, Nigeria, Ovikuomagbe Oyedele, Ph.D., Faculty Member and Head of Department, Department of Economics, Veronica Adeleke School of Social Sciences, Babcock University, Ilishan-Remo, Ogun State, Nigeria, Chantal Epie, Professor and Dean, School of Management and Social Sciences, Pan-Atlantic University, Ibeju-Lekki, Lagos, Nigeria, Sheriffdeen A. Tella, Professor, Department of Economics, Olabisi Onabanjo University, Ogun State, Nigeria, Oluseye Ajuwon, Ph.D., Faculty Member, Department of Economics, Faculty of Social Sciences, University of Lagos, Nigeria, Darlington Agholor, Ph.D., Faculty Member and Dean, School of Science and Technology, Pan-Atlantic University, Ibeju-Lekki, Lagos, Nigeria, Stephen Maitanmi, Ph.D., Faculty Member, School of Computing and Engineering Sciences, Babcock University, Ilishan-Remo, Ogun State, Nigeria, and the support of Ayobami Adeleye, Deborah Adejola, Tolani Obakoya, Bolaji Martins and Omowumi Momoh, Department of Economics, Veronica Adeleke School of Sciences, Babcock University, Ilishan-Remo, Ogun State, Nigeria, and Juanita Omeokachie, Babcock University, IlishanRemo, Ogun State, Nigeria. 


\begin{tabular}{lcc}
\hline \multicolumn{1}{c}{ Asset Classification } & Percentage of AMCON Portfolio & Number of Loans \\
\hline Combination of Assets & $13 \%$ & 103 \\
Debentures & $15 \%$ & 295 \\
Mortgage & $20 \%$ & 2,096 \\
Others & $6 \%$ & 795 \\
Shares & $22 \%$ & 4,105 \\
Shares \& Mortgage & $4 \%$ & 20 \\
Unsecured & $22 \%$ & 5,123 \\
\hline Total & $100 \%$ & 12,537 \\
\hline Soure: AMCON(2019) & & \\
\hline
\end{tabular}

Source: AMCON (2019)

Table 1. AMCON's Asset Classification 
Uddin et al.

Appendix-II

\begin{tabular}{lcc}
\hline \multicolumn{1}{c}{ Loan Distribution } & Percentage of AMCON Portfolio & Number of Loans \\
\hline Over N10b & $40 \%$ & 62 \\
Between N1b and N10b & $37 \%$ & 431 \\
Between N100m and N1b & $16 \%$ & 1,998 \\
Between N100m and below & $7 \%$ & 10,046 \\
\hline Total & $100 \%$ & 12,537 \\
\hline
\end{tabular}

Source: AMCON (2019)

Table 2. AMCON's Loan Distribution 


\begin{tabular}{|c|c|c|c|c|}
\hline Author(s) & $\begin{array}{l}\text { Country / } \\
\text { Countries }\end{array}$ & $\begin{array}{l}\text { Sample } \\
\text { Period }\end{array}$ & Methodology & Results/Conclusion of the Study \\
\hline Okheshimi (2020) & Nigeria & $\begin{array}{l}2009 \\
2018\end{array}$ & Panel OLS & $\begin{array}{l}\text { The findings showed that the money } \\
\text { supply has a significant relationship } \\
\text { with the asset quality indicator of } \\
\text { commercial banks, while other } \\
\text { monetary policy variables did not. }\end{array}$ \\
\hline $\begin{array}{l}\text { Ogbeifun and Akinola } \\
(2019)\end{array}$ & Nigeria & $\begin{array}{l}1997 \\
2016\end{array}$ & OLS & $\begin{array}{l}\text { The study concluded that monetary } \\
\text { policy tools have no significant effect } \\
\text { on the financial performance of } \\
\text { DMBs. }\end{array}$ \\
\hline $\begin{array}{l}\text { Onoh and } \\
\text { Nwachukwu (2017) }\end{array}$ & Nigeria & $\begin{array}{l}1980 \\
2015 \\
\end{array}$ & OLS & $\begin{array}{l}\text { Monetary policy affects commercial } \\
\text { banks' credit delivery. }\end{array}$ \\
\hline $\begin{array}{l}\text { Okorie and Agu } \\
(2015)\end{array}$ & Nigeria & $\begin{array}{l}2002 \\
2010\end{array}$ & DEA & $\begin{array}{l}\text { The study showed improvement in } \\
\text { Nigerian banks' performance and } \\
\text { efficiency due to the Nigerian banking } \\
\text { sector reforms. }\end{array}$ \\
\hline $\begin{array}{l}\text { Ekong and Udonwa } \\
(2015)\end{array}$ & Nigeria & $\begin{array}{l}1970 \\
2012\end{array}$ & $\begin{array}{l}\text { Co-integration, } \\
\text { VECM, and } \\
\text { Chow test }\end{array}$ & $\begin{array}{l}\text { The study concluded that banking } \\
\text { sector reforms impacted positively on } \\
\text { commercial banks' performance. }\end{array}$ \\
\hline $\begin{array}{l}\text { Akomolafe et al. } \\
(2015)\end{array}$ & Nigeria & $\begin{array}{l}2003 \\
2013\end{array}$ & Panel OLS & $\begin{array}{l}\text { The results show a positive } \\
\text { relationship between monetary policy } \\
\text { variables (money supply and interest } \\
\text { rate) and commercial banks' } \\
\text { performance. }\end{array}$ \\
\hline Ayodele (2014) & Nigeria & $\begin{array}{l}1988 \\
2008\end{array}$ & VECM & $\begin{array}{l}\text { The results concluded the existence of } \\
\text { a long-run relationship between } \\
\text { exchange rate, interest rate, liquidity } \\
\text { ratio, money supply, and commercial } \\
\text { banks' loans and advances. }\end{array}$ \\
\hline $\begin{array}{l}\text { Schularick and Taylor } \\
\text { (2012) }\end{array}$ & $\begin{array}{l}14 \text { developed } \\
\text { countries }\end{array}$ & $\begin{array}{l}1870 \\
2008\end{array}$ & $\begin{array}{l}\text { Panel OLS } \\
\text { (Linear) } \\
\text { Probability } \\
\text { model }\end{array}$ & $\begin{array}{l}\text { The study revealed monetary policy / } \\
\text { monetary and regulatory frameworks } \\
\text { did not well manage DMBs' } \\
\text { performance. }\end{array}$ \\
\hline $\begin{array}{l}\text { Olajide, Asaolu, and } \\
\text { Jegede (2011) }\end{array}$ & Nigeria & $\begin{array}{l}1995 \\
2004\end{array}$ & $\begin{array}{l}\text { Pooled panel } \\
\text { regression }\end{array}$ & $\begin{array}{l}\text { The results showed financial sector } \\
\text { reforms impacted negatively } \\
\text { commercial banks' performance. }\end{array}$ \\
\hline
\end{tabular}

Source: Authors' Presentation

Note: OLS-ordinary least squares, VECM-vector error correction model, DEA-data envelopment

Table 3. Empirical Evidence on Central Bank Monetary Policy and DMBs Performance 
Uddin et al.

Appendix-IV

\begin{tabular}{|c|c|c|c|c|c|}
\hline Author(s) & $\begin{array}{l}\text { Country / } \\
\text { Countries }\end{array}$ & \multicolumn{2}{|c|}{$\begin{array}{c}\text { Sample } \\
\text { Period }\end{array}$} & Methodology & Results/Conclusion of the Study \\
\hline Godwin (2017) & South Africa & $\begin{array}{l}1998 \\
2017\end{array}$ & to & $\begin{array}{l}\text { Thematic and } \\
\text { Comparative } \\
\text { Review }\end{array}$ & $\begin{array}{l}\text { The study concluded the Twin Peaks } \\
\text { model of financial regulation to be of } \\
\text { superior benefits, compared to the } \\
\text { 'super-regulator' model. }\end{array}$ \\
\hline Caruana (2014) & Africa & $\begin{array}{l}2009 \\
2013\end{array}$ & to & $\begin{array}{l}\text { Thematic } \\
\text { Review }\end{array}$ & $\begin{array}{l}\text { The study concluded that good } \\
\text { macroeconomic policy requires } \\
\text { mechanisms that ensure appropriate } \\
\text { coordination but avoid a potential } \\
\text { conflict of interest and that } \\
\text { responsibility for financial stability } \\
\text { will almost always be shared with } \\
\text { other bodies. }\end{array}$ \\
\hline $\begin{array}{l}\text { Botha and Makina } \\
\text { (2011) }\end{array}$ & South Africa & $\begin{array}{l}1965 \\
2010\end{array}$ & $\mathrm{O}$ & $\begin{array}{l}\text { Thematic and } \\
\text { Comparative } \\
\text { Review }\end{array}$ & $\begin{array}{l}\text { The study attested to the twin peaks } \\
\text { regulatory approach as of more } \\
\text { benefits to the silos (institutional) } \\
\text { approach to financial regulation and } \\
\text { supervision. }\end{array}$ \\
\hline
\end{tabular}

Table 4. Reviews on Financial System Supervisory Institutions and Central Bank Monetary Policy 


\begin{tabular}{lc}
\hline \multicolumn{1}{c}{ Institutions whom databases/depositories were accessed } & $\begin{array}{c}\text { Number of } \\
\text { relevant articles } \\
\text { sourced }\end{array}$ \\
\hline Central Bank of Nigeria - CBN, Abuja, Nigeria (and her allied financial agencies) & 24 \\
European Central Bank - ECB, Frankfurt, Germany & 3 \\
Bank for International Settlements -BIS, Basel, Switzerland & 3 \\
International Bank for Reconstruction and Development - IBRD / World Bank, & 2 \\
Washington, D. C., United States of America (USA) & \\
International Monetary Fund - IMF, Washington, D. C., USA & 3 \\
National Bureau for Economic Research - NBER, Cambridge, Massachusetts, USA & 1 \\
American Economic Association - AEA, Nashville, Tennessee, USA & 4 \\
Oxford University Press - OUP, Oxford, United Kingdom & 4 \\
Cambridge University Press, Cambridge, United Kingdom & 5 \\
Routledge - Taylor \& Francis Group, Informa UK Limited (Taylor \& Francis & 5 \\
Online), Oxfordshire, United Kingdom & 7 \\
Springer Online, Springer Nature, Switzerland AG & 9 \\
ScienceDirect, Elsevier B. V & \\
\hline Source: Authors' Presentation &
\end{tabular}

Table 5. Description of the Search Strategy Implemented ${ }^{6}$ 


\section{Uddin et al.}

\section{Endnotes}

${ }^{1}$ Schularick and Taylor (2012), in line with previous studies, defines financial crises as events during which a country's banking sector experiences bank runs, sharp increases in default rates accompanied by large losses of capital that result in public intervention, bankruptcy, or forced merger of financial institutions.

${ }^{2}$ The key output sectors that make up the real sector of an economy are the primary sector (agriculture \& mining), the secondary sector (manufacturing and building \& construction) and the tertiary sector (services and commerce) (see Oduyemi, 2013; Uddin and Oserei, 2019)

${ }^{3}$ These banks tagged as Bridged Banks: Mainstreet Bank, Keystone Bank, and Enterprise Bank (The Sun, 2015; AMCON, 2019). ${ }^{4}$ Here, we also acknowledge that the consideration of specifics in pre-existing empirical published literature could inform a pathway for another empirical investigation (or journey) in face of mixed conclusions as mentioned above.

${ }^{5}$ This seemingly new but emerging qualitative research method adopted herein had been somewhat uncommon (or rarely used), as a stand-alone research method in economic literature, whereas the same method relatively becoming popular in the pure (and allied) sciences, humanities, and management sciences (Baumeister and Leary, 1997; Burton, 2014; Snyder, 2019; Wong et al., 2013 etc.).

${ }^{6}$ For record purposes, prudence requires we mention that five of the relevant literature sourced from the CBN and another five miscellaneous (but also relevant) literature sourced through google scholar - a total of 10 - are (policy) documents which considered the COVID-19 pandemic era, while the remaining 19 relevant literature sourced from the CBN were of the preCOVID-19 era in Nigeria i.e., before March 2020. Also, all other relevant literature sourced from other databases/depositories were of the pre-COVID-19 era. For a testament of actions that could be implemented going forward during this COVID-19 pandemic and post COVID-19, see Business Day Newspaper (2020), CBN (2020b; 2020c; 2020d; 2020e; 2020f), CNBC (2020), Evans (2020), NCDC (2020), and WHO (2020). 